\title{
Impak kerja pembinaan baru terhadap bangunan sekitar: Kajian keretakan bangunan di Pusat Bandar Puchong, Selangor
}

\author{
Z.M. Noor ${ }^{1}$, A.I. Che-Ani ${ }^{1}$, M.M. Tahir ${ }^{1}$, N.A.G. Abdullah ${ }^{1}$, M. Surat $^{1}$ \\ ${ }^{1}$ Jabatan Seni Bina, Fakulti Kejuruteraan dan Alam Bina, \\ Universiti Kebangsaan Malaysia \\ adiirfan@gmail.com
}

\begin{abstract}
Abstrak
Kebelakangan ini, terdapat beberapa buah kes aduan tentang impak kerja pembinaan terhadap fizikal bangunan sekitar dilaporkan dalam akhbar-akhbar tempatan. Sehubungan itu, kajian dijalankan terhadap sebuah kes aduan yang diterima oleh salah sebuah Pihak Berkuasa Tempatan (PBT) iaitu Majlis Perbandaran Subang Jaya (MPSJ) daripada pemilik-pemilik bangunan di Taman Wawasan, Pusat Bandar Puchong, Selangor tentang impak kerja pembinaan baru berhampiran terhadap fizikal bangunan mereka. Hasil kajian mendapati wujud hubung kait antara kerja-kerja pembinaan baru berhampiran yang dijalankan dengan fizikal bangunan-bangunan kajian terlibat. Walau bagaimanapun, sama ada impak kerja pembinaan baru tersebut ialah punca primer atau sekunder terhadap keretakan bangunan yang berlaku pada bangunan-bangunan kajian adalah sukar ditentukan. Oleh itu, dicadangkan MPSJ khususnya dan PBT amnya mewujudkan satu garis panduan di peringkat tempatan iaitu bagi setiap pembinaan baru yang akan dijalankan mestilah dilakukan terlebih dahulu pemeriksaan terhadap keadaan bangunan-bangunan sedia ada di sekitarnya. Laporan keadaan bangunan tersebut dapat diguna pakai sekiranya berlaku dakwaan daripada pemilik-pemilik bangunan sekitar terbabit tentang impak kerja pembinaan baru berhampiran terhadap fizikal bangunan mereka.
\end{abstract}

Kata kunci: bangunan, impak pembinaan, pemeriksaan visual, retak

\begin{abstract}
There are several cases of complaint lately about the impact of construction work to the physical condition of surrounding building reported in local newspaper. Thus, a study conducted on a complaint case that has been received by one of the Local Authority (PBT) namely Subang Jaya Municipal Council (MPSJ) from the building owners in Taman Wawasan, Pusat Bandar Puchong, Selangor about the impact of the adjacent new construction work on their physical building condition. The results found that there is relation between the adjacent new construction works with the physical buildings involved. However, the primary cause of building crack is difficult to determine. Therefore, it is proposed that MPSJ has to establish a guideline at the local level, namely for each new construction to be carried out, there must prepare an inspection report on condition of the existing buildings in the surrounding area. This building condition report will be used in the event of claims received from the surrounding
\end{abstract}


building owners about the impact of the adjacent new construction work on their physical building condition.

Keywords: building, construction impact, crack, visual inspection

\section{Pengenalan}

Pada tahun 2007, industri pembinaan di Malaysia telah menyumbang 2.5 peratus kepada Keluaran Dalam Negara Kasar dan menyediakan peluang pekerjaan kepada kira-kira 800000 orang (Construction Industry Development Board, 2007). Aktiviti pembinaan ini memberi impak terhadap ekonomi, sosial, alam sekitar dan bangunan sekitar.

Kajian yang telah dijalankan oleh Ruzana (1999) mendapati pembinaan Lapangan Terbang Antarabangsa Kuala Lumpur (KLIA) mendatangkan banyak kebaikan dalam aspek sosioekonomi terhadap penduduk di sekitar daerah Sepang khasnya dan penduduk Malaysia amnya selepas KLIA beroperasi. Walau bagaimanapun, impak negatif terhadap alam sekitar seperti pencemaran air, udara dan bunyi berlaku dengan ketara ketika KLIA dalam fasa pembinaan. Hasil kajian yang telah dijalankan oleh Rahaya (2006) dan Zuzyanna (2007) masing-masing di Kemaman dan Seremban juga mendapati impak negatif terhadap alam sekitar seperti pencemaran air, udara, bunyi bising dan sisa pepejal berlaku akibat aktiviti pembangunan di keduadua buah kawasan tersebut.

Selain itu, akhbar Berita Harian (2008) bertarikh 9 Mei telah melaporkan tentang pemilik-pemilik rumah di Taman Sutera Prima, Seberang Jaya yang mendakwa kerja pembinaan pangsapuri 38 tingkat di kawasan berhampiran oleh sebuah syarikat pemaju menyebabkan rumah mereka mengalami keretakan serius. Harian Metro (2008) bertarikh 18 Disember pula telah melaporkan dakwaan seorang pemilik rumah di Kampung Kuala Pari, Ipoh tentang rumahnya yang hampir roboh akibat kerja melebar dan mendalamkan sungai berhampiran oleh Majlis Bandaraya Ipoh.

Dalam situasi ini, pemilik-pemilik bangunan terbabit membuat aduan terus kepada PBT tentang impak kerja pembinaan berhampiran terhadap fizikal bangunan mereka baik projek yang dijalankan oleh syarikat swasta mahupun kerajaan. Terdapat juga situasi yang mana pemilik-pemilik bangunan terbabit membuat aduan tentang kes seumpamanya kepada wakil rakyat setempat atau pemaju pembinaan berhampiran 
tersebut namun akhirnya akan dirujuk kepada PBT jua. Sehubungan itu, kajian ini dijalankan untuk mengenal pasti langkah komprehensif yang perlu dilakukan oleh PBT bagi menyelesaikan kes aduan yang diterima daripada pemilik-pemilik bangunan tentang impak kerja pembinaan berhampiran terhadap fizikal bangunan mereka.

\section{Kerangka teoretikal keretakan bangunan}

Menurut Eldridge (1976), Building Research Establishment (BRE) (1991), Carillion (2001), Johnson (2002), Panchdhari (2003) dan Ahmad (2004), jenis-jenis keretakan bangunan boleh dikategorikan kepada tahap keretakan iaitu sama ada retak estetik, kebolehkhidmatan atau kestabilan, bentuk keretakan iaitu retak melintang, menegak, pepenjuru atau rawak dan lebar keretakan daripada retak rerambut hingga besar di samping mengambil kira faktor lokasi, struktur atau elemen bangunan berlakunya keretakan. Berdasarkan data-data sumber sekunder tersebut, variabel-variabel kajian telah dikenal pasti dan satu kerangka teoretikal keretakan bangunan telah dibentuk. Rajah 1 menunjukkan kerangka teoretikal kajian ini. 


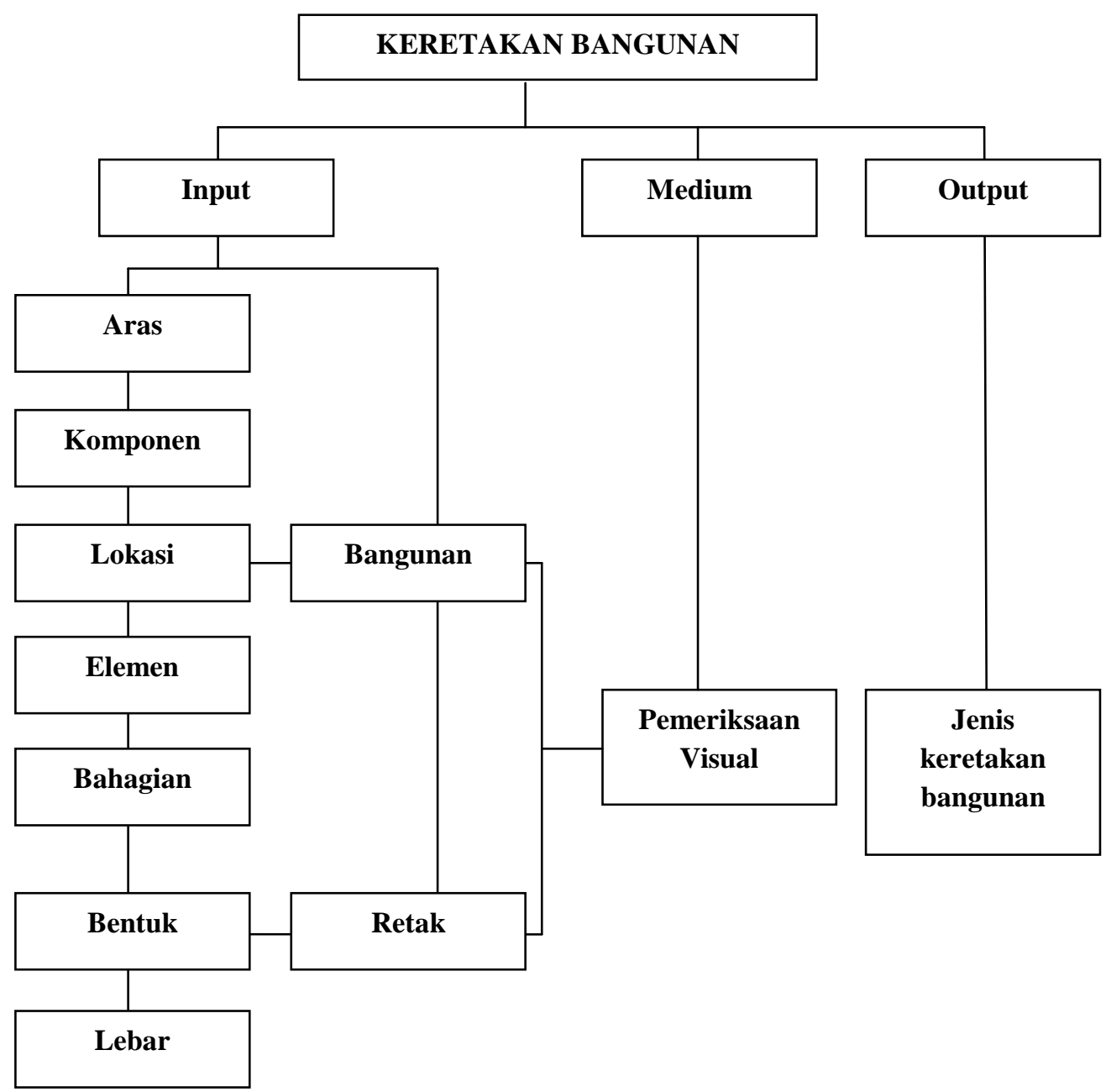

Rajah 1: Kerangka teoretikal keretakan bangunan.

Di samping itu, Eldridge (1976) menekankan faktor penggunaan bangunan dan persekitaran menyebabkan keretakan bangunan berlaku manakala Carillion (2001) menekankan faktor kesilapan pemilihan bahan binaan dan persekitaran menyebabkan kecacatan bangunan. Panchdhari (2003) pula menekankan faktor persekitaran dan Ahmad (2004) menjelaskan faktor kesilapan kerja pembinaan dan persekitaran sebagai faktor-faktor yang banyak menyebabkan keretakan bangunan berlaku. Justeru, faktor persekitaran seperti pergerakan tanah baik secara semula jadi atau akibat aktiviti manusia, beban lebih, agen perosak, perubahan suhu dan gegaran perlu diberikan 
perhatian yang sewajarnya sebagai faktor utama yang menyebabkan berlakunya keretakan bangunan.

Sementara itu, menurut Jabatan Kerja Raya (2007), struktur bangunan rendah tipikal terdiri daripada rasuk, papak lantai, dinding konkrit, tangga, tiang, asas dan tetulang. Struktur ialah anggota-anggota yang dipasang antara satu sama lain dengan penyambungan yang sesuai dan selamat bagi menghasilkan suatu kerangka yang berupaya menanggung beban yang dijangkakan. Terdapat empat kaedah pembinaan iaitu konvensional, tuangan di situ, komposit dan pasang siap (Nuzul Azam et al. 2005).

\section{Metodologi}

Kajian ini dijalankan terhadap sebuah kes aduan yang diterima oleh salah sebuah PBT iaitu MPSJ daripada pemilik-pemilik bangunan di Taman Wawasan, Pusat Bandar Puchong tentang impak kerja pembinaan baru berhampiran terhadap fizikal bangunan mereka. Tujuan kajian ini dijalankan adalah mengenal pasti jenis-jenis dan punca-punca keretakan bangunan terlibat seperti yang didakwa oleh pemilik-pemilik bangunan terbabit serta hubung kait antara fizikal bangunan-bangunan terlibat dengan kerja pembinaan baru berhampirannya. Pendekatan yang digunakan ialah kajian kuantitatif yang melibatkan analisis bernombor atau statistik data. Sampel kajian terdiri daripada 28 buah rumah teres dua tingkat di Taman Wawasan, Pusat Bandar Puchong dan instrumen yang digunakan ialah borang pemeriksaan bagi melakukan pemeriksaan bangunan. Rajah 2 menunjukkan pelan tapak bangunan-bangunan terlibat. 


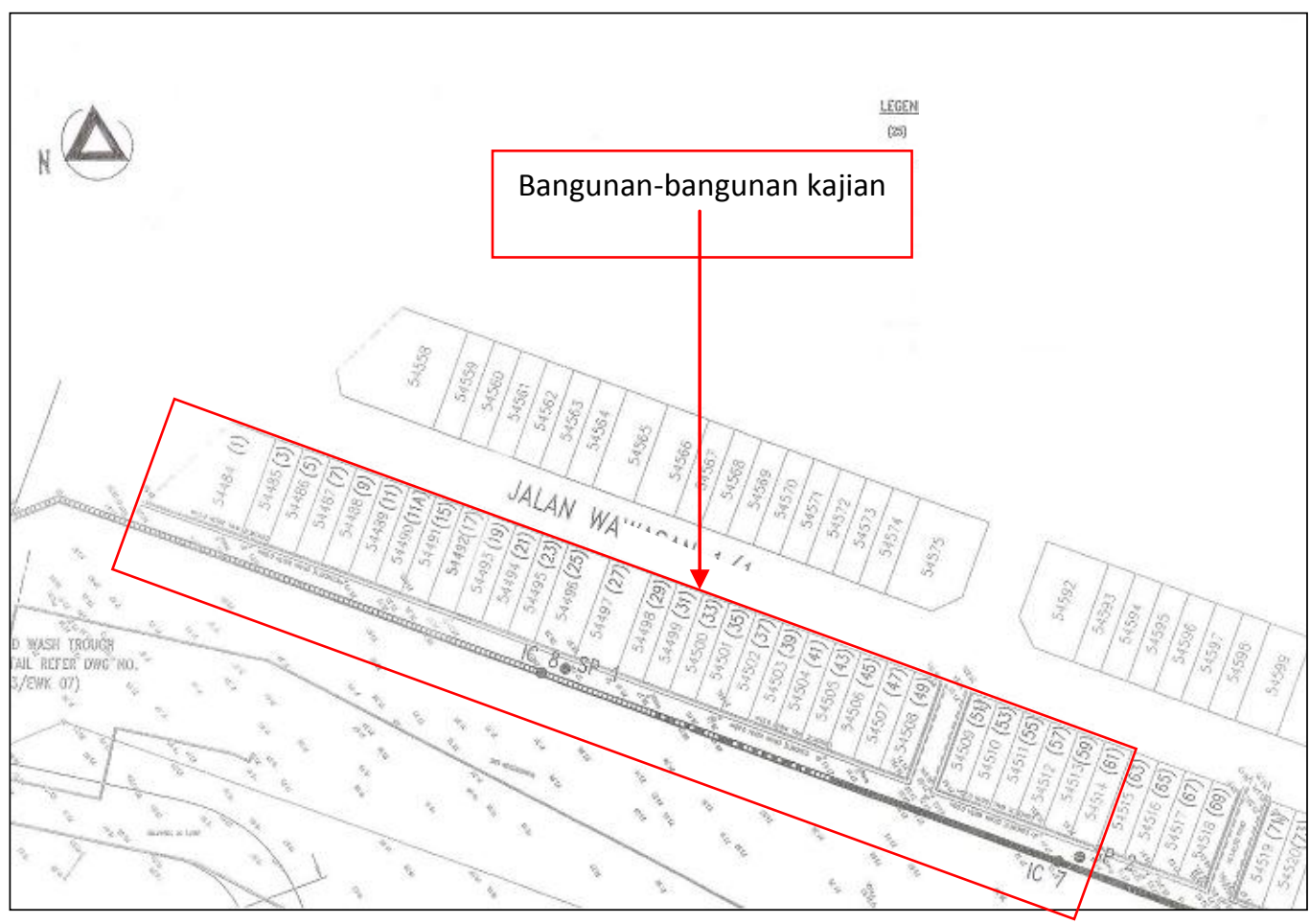

Rajah 2: Pelan tapak.

Pemeriksaan bangunan terbahagi kepada tiga peringkat iaitu kerja-kerja awal, pemeriksaan visual dan penyediaan laporan keadaan bangunan. Kerja-kerja awal adalah seperti tinjauan awal, mengatur akses, menyelidik dan menyediakan peralatan pemeriksaan. Kerja pemeriksaan bangunan secara visual pula bermula setelah memperoleh kebenaran dan mengatur temu janji dengan pemilik-pemilik bangunan terbabit. Seterusnya, data-data sumber primer telah dianalisis menggunakan perisian Microsoft Office Excel dan Statistical Package for the Social Sciences.

Kes aduan daripada pemilik-pemilik bangunan di Taman Wawasan, Pusat Bandar Puchong terbabit dipilih sebagai kajian disebabkan ianya adalah antara kes terkini yang sedang dikendalikan oleh MPSJ dan masih dalam peringkat mengenal pasti langkah penyelesaian terbaik. Oleh sebab sampel kajian adalah kurang daripada 50 iaitu sebanyak 28 buah bangunan, korelasi Spearman digunakan untuk mengukur hubung kait antara variabel-variabel kajian. Koefisien korelasi atau kekuatan hubungan adalah berdasarkan julat antara -1.0 hingga +1.0 . Nilai 0 pula menunjukkan tiada hubungan langsung antara variabel-variabel kajian. Bagi menginterpretasi kesignifikan korelasi 
antara variabel-variabel yang terlibat maka nilai $\mathrm{p}$ dirujuk iaitu terdapat hubungan signifikan apabila nilai $\mathrm{p} \leq 0.01$ atau $\leq 0.05$ (Foster 2001).

\section{Perbincangan penemuan}

Berdasarkan pemeriksaan visual yang dilakukan terhadap 28 buah bangunan kajian, didapati sebanyak 5 buah bangunan mempunyai bahagian bangunan asal sahaja iaitu tiada pembesaran atau penyambungan dilakukan pada bangunan asal tersebut. Sebanyak 23 buah bangunan lagi terdapat pembesaran atau penyambungan pada bangunan asal iaitu 13 buah bangunan terdapat bahagian bangunan tambahan di tingkat bawah bahagian belakang bangunan asal dan 10 buah bangunan lagi terdapat bahagian bangunan tambahan di kedua-dua tingkat bawah dan atas bahagian belakang bangunan asal. Walau bagaimanapun, kesemua 28 buah bangunan kajian terdapat pengubahsuaian pada kemasan dinding tembok dan lantai kaki lima di anjung bahagian hadapan bangunan asal. Jadual 1 menunjukkan taburan frekuensi retak bagi setiap bangunan kajian ini. Kategori lebar retak bangunan adalah berdasarkan kepada nota praktis yang disediakan oleh BRE (1991).

Berdasarkan Jadual 1, didapati frekuensi retak adalah semakin kecil apabila lebar retak semakin besar. Peratusan kategori lebar retak sangat kecil adalah paling tinggi iaitu sebanyak $61.3 \%$ diikuti retak kecil $20.0 \%$, retak sederhana $12.8 \%$, retak besar 3.2\% dan retak sangat besar $2.6 \%$ bagi keseluruhan bangunan kajian. Di samping itu, Jadual 2 menunjukkan taburan frekuensi retak mengikut fizikal bangunan bagi keseluruhan bangunan kajian ini. 
Jadual 1: Taburan frekuensi retak bagi setiap bangunan kajian.

\begin{tabular}{|c|c|c|c|c|c|}
\hline \multirow{2}{*}{$\begin{array}{l}\text { Nama } \\
\text { Bangunan }\end{array}$} & \multicolumn{5}{|c|}{ Lebar Retak (mm) } \\
\hline & $\begin{array}{c}\text { Sangat } \\
\text { Kecil } \\
(<1.0)\end{array}$ & $\begin{array}{l}\text { Kecil } \\
(<5.0)\end{array}$ & $\begin{array}{l}\text { Sederhana } \\
\qquad(<\mathbf{1 5 . 0})\end{array}$ & $\begin{array}{c}\text { Besar } \\
(<25.0)\end{array}$ & $\begin{array}{c}\text { Sangat } \\
\text { Besar } \\
(\geq 25.0)\end{array}$ \\
\hline Rumah 1 & 7 & 12 & 1 & 1 & 0 \\
\hline Rumah 2 & 25 & 4 & 1 & 0 & 1 \\
\hline Rumah 3 & 17 & 0 & 1 & 0 & 0 \\
\hline Rumah 4 & 3 & 10 & 3 & 0 & 0 \\
\hline Rumah 5 & 11 & 0 & 2 & 0 & 0 \\
\hline Rumah 6 & 14 & 0 & 6 & 0 & 0 \\
\hline Rumah 7 & 14 & 1 & 0 & 0 & 0 \\
\hline Rumah 8 & 15 & 8 & 2 & 0 & 0 \\
\hline Rumah 9 & 11 & 1 & 2 & 1 & 0 \\
\hline Rumah 10 & 8 & 0 & 3 & 0 & 0 \\
\hline Rumah 11 & 19 & 0 & 1 & 0 & 0 \\
\hline Rumah 12 & 6 & 7 & 1 & 0 & 0 \\
\hline Rumah 13 & 11 & 6 & 6 & 0 & 2 \\
\hline Rumah 14 & 12 & 3 & 5 & 0 & 1 \\
\hline Rumah 15 & 4 & 6 & 2 & 2 & 4 \\
\hline Rumah 16 & 13 & 1 & 7 & 0 & 1 \\
\hline
\end{tabular}




\begin{tabular}{|lccccc|} 
Rumah 17 & 8 & 3 & 5 & 0 & 0 \\
Rumah 18 & 8 & 8 & 1 & 7 & 1 \\
Rumah 19 & 8 & 5 & 6 & 3 & 3 \\
Rumah 20 & 15 & 5 & 1 & 1 & 0 \\
Rumah 21 & 5 & 2 & 0 & 1 & 0 \\
Rumah 22 & 13 & 2 & 0 & 0 & 0 \\
Rumah 23 & 0 & 10 & 3 & 0 & 0 \\
Rumah 24 & 0 & 2 & 1 & 0 & 0 \\
Rumah 25 & 2 & 2 & 1 & 0 & 0 \\
Rumah 26 & 16 & 0 & 2 & 0 & 0 \\
Rumah 27 & 16 & 0 & 1 & 0 & 0 \\
Rumah 28 & 25 & 2 & 0 & 0 & 0 \\
Jumlah & $\mathbf{3 0 6}$ & $\mathbf{1 0 0}$ & $\mathbf{6 4}$ & $\mathbf{1 6}$ & $\mathbf{1 3}$ \\
& & & & & \\
\hline
\end{tabular}


Jadual 2: Taburan frekuensi retak mengikut fizikal bangunan bagi keseluruhan bangunan kajian.

\begin{tabular}{|c|c|c|c|c|c|}
\hline \multirow[t]{2}{*}{ Perkara } & \multicolumn{5}{|c|}{ Lebar Retak (mm) } \\
\hline & $\begin{array}{c}\text { Sangat } \\
\text { Kecil } \\
(<1.0)\end{array}$ & $\begin{array}{l}\text { Kecil } \\
(<5.0)\end{array}$ & $\begin{array}{c}\text { Sederhana } \\
(<\mathbf{1 5 . 0})\end{array}$ & $\begin{array}{c}\text { Besar } \\
(<25.0)\end{array}$ & $\begin{array}{c}\text { Sangat } \\
\text { Besar } \\
(\geq 25.0)\end{array}$ \\
\hline \multicolumn{6}{|l|}{ Aras Bangunan } \\
\hline Tingkat bawah & 159 & 75 & 56 & 7 & 8 \\
\hline Tingkat atas & 147 & 25 & 8 & 9 & 5 \\
\hline \multicolumn{6}{|c|}{ Komponen Bangunan } \\
\hline Anjung & 35 & 25 & 26 & 3 & 2 \\
\hline Ruang tamu & 30 & 11 & 0 & 0 & 1 \\
\hline Dapur & 49 & 27 & 20 & 4 & 2 \\
\hline Bilik utiliti & 31 & 7 & 8 & 0 & 3 \\
\hline Tandas 3 & 14 & 5 & 2 & 0 & 0 \\
\hline Ruang keluarga & 42 & 9 & 0 & 0 & 0 \\
\hline Bilik 1 & 22 & 3 & 0 & 0 & 0 \\
\hline Bilik 2 & 31 & 5 & 3 & 5 & 3 \\
\hline Bilik 3 & 31 & 4 & 5 & 4 & 2 \\
\hline Tandas 1 & 9 & 3 & 0 & 0 & 0 \\
\hline Tandas 2 & 12 & 1 & 0 & 0 & 0 \\
\hline \multicolumn{6}{|c|}{ Lokasi Bangunan } \\
\hline Luaran & 61 & 37 & 29 & 4 & 4 \\
\hline
\end{tabular}




\begin{tabular}{|c|c|c|c|c|c|}
\hline Dalaman & 245 & 63 & 35 & 12 & 9 \\
\hline \multicolumn{6}{|c|}{ Elemen Bangunan } \\
\hline Dinding & 256 & 63 & 28 & 9 & 8 \\
\hline Dinding tembok & 11 & 11 & 10 & 3 & 2 \\
\hline Rasuk & 5 & 2 & 0 & 0 & 0 \\
\hline Tiang & 3 & 3 & 0 & 0 & 0 \\
\hline Lantai & 9 & 8 & 8 & 3 & 2 \\
\hline Lantai kaki lima & 3 & 12 & 17 & 1 & 1 \\
\hline Siling & 19 & 1 & 1 & 0 & 0 \\
\hline \multicolumn{6}{|c|}{ Bentuk Retak (bagi elemen dinding, dinding tembok, rasuk dan tiang sahaja) } \\
\hline Melintang & 86 & 13 & 3 & 0 & 0 \\
\hline $\begin{array}{l}\text { Melintang dan } \\
\text { menegak }\end{array}$ & 43 & 6 & 1 & 0 & 0 \\
\hline $\begin{array}{l}\text { Melintang dan } \\
\text { pepenjuru }\end{array}$ & 10 & 2 & 0 & 0 & 1 \\
\hline Menegak & 96 & 47 & 26 & 12 & 9 \\
\hline $\begin{array}{l}\text { Menegak dan } \\
\text { pepenjuru }\end{array}$ & 2 & 0 & 2 & 0 & 0 \\
\hline Pepenjuru & 24 & 9 & 6 & 0 & 0 \\
\hline Rawak & 14 & 2 & 0 & 0 & 0 \\
\hline \multicolumn{6}{|c|}{ Bahagian Bangunan } \\
\hline Asal & 231 & 60 & 17 & 1 & 1 \\
\hline \multicolumn{6}{|l|}{$\begin{array}{l}\text { Tambahan/ } \\
\text { ubah suaian }\end{array}$} \\
\hline
\end{tabular}


Berdasarkan Jadual 2, didapati elemen dinding mencatatkan frekuensi retak paling tinggi berbanding elemen-elemen bangunan yang lain iaitu sebanyak 364 retak bagi kategori lebar retak sangat kecil hingga retak sangat besar. Ini sejajar dengan struktur bangunan-bangunan kajian adalah paling banyak terdiri daripada dinding bata di samping kerangka konkrit bertetulang. Bentuk keretakan yang paling banyak berlaku pula adalah retak menegak iaitu sebanyak 190 retak juga bagi kategori lebar retak sangat kecil hingga retak sangat besar. Retak menegak paling banyak berlaku pada elemen dinding dijangka berpunca daripada pengembangan dan pengecutan bata tanah liat akibat perubahan kandungan kelembapan dan perubahan suhu. Menurut Carillion (2001), kebanyakan keretakan berlaku pada peringkat awal hayat bangunan dengan lebar retak rerambut dan semakin membesar sehingga bangunan berusia 20 tahun dengan lebar retak maksimum $680.0 \mathrm{~mm}$. Ini sejajar dengan maklumat awal yang diperoleh menunjukkan bangunan-bangunan kajian adalah berusia 12 tahun. Rajah 3 menunjukkan contoh-contoh bentuk keretakan bangunan-bangunan kajian.

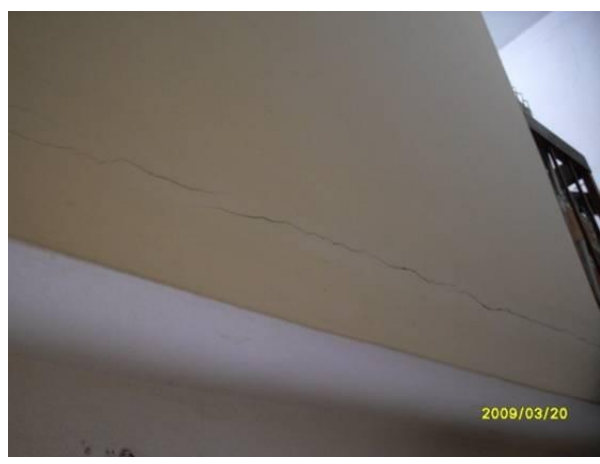

Retak melintang

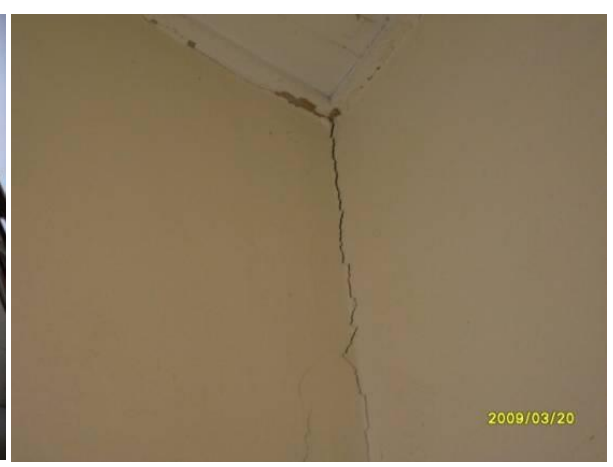

Retak menegak 


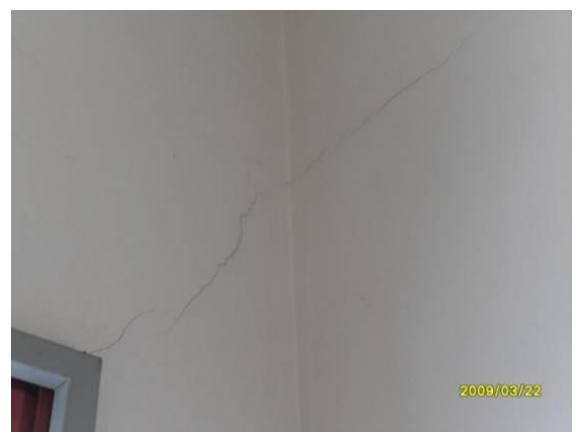

Retak pepenjuru

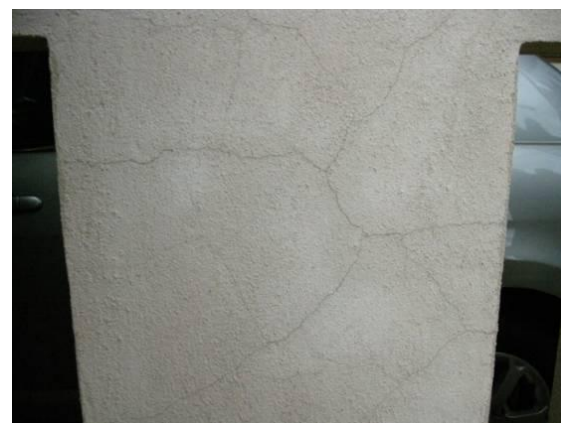

Retak rawak

\section{Rajah 3: Bentuk-bentuk keretakan bangunan kajian.}

Selain itu, didapati frekuensi retak bagi kategori lebar retak sangat kecil dan retak kecil bagi bahagian bangunan asal mengatasi frekuensi retak bagi kategori lebar retak sangat kecil dan retak kecil bagi bahagian bangunan tambahan/ ubah suaian iaitu sebanyak 291 retak berbanding 115 retak. Walau bagaimanapun, frekuensi retak bagi kategori lebar retak sederhana, retak besar dan retak sangat besar bagi bahagian bangunan tambahan/ ubah suaian adalah lebih tinggi daripada frekuensi retak bagi kategori lebar retak sederhana, retak besar dan retak sangat besar bagi bahagian bangunan asal iaitu sebanyak 74 retak berbanding 19 retak. Frekuensi retak bagi bahagian bangunan asal adalah semakin kecil apabila lebar retak semakin besar. Rajah 4 menunjukkan contoh-contoh kategori lebar retak bangunan-bangunan kajian.

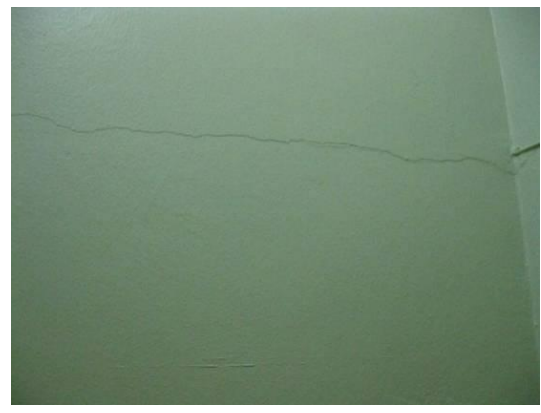

Retak sangat kecil ( $0.5 \mathrm{~mm}$ lebar) pada dinding di tandas 3 Rumah 16

(Bahagian bangunan asal di tingkat bawah)

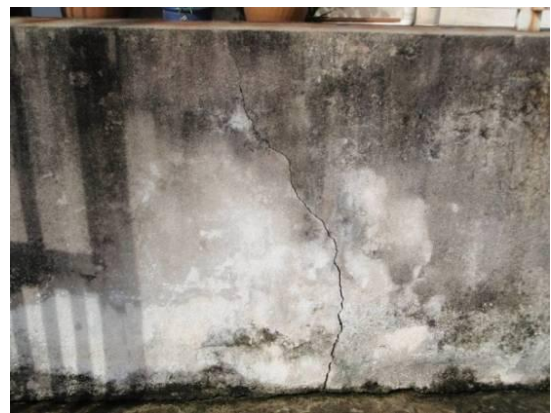

Retak kecil (3.0mm lebar) pada dinding tembok di anjung Rumah 8

(Bahagian bangunan ubah suaian di tingkat bawah) 


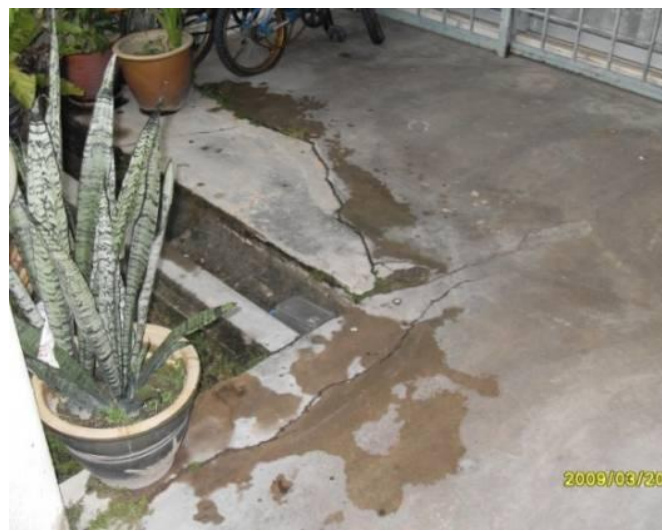

Retak sederhana (5.0mm lebar) pada lantai kaki lima di anjung Rumah 3

(Bahagian bangunan asal di tingkat bawah)

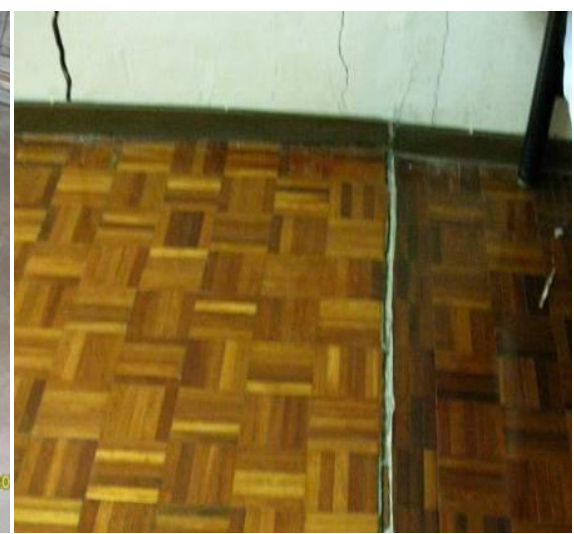

Retak besar (21.1mm lebar) pada lantai di bilik 2 Rumah 19

(Bahagian bangunan tambahan di tingkat atas)

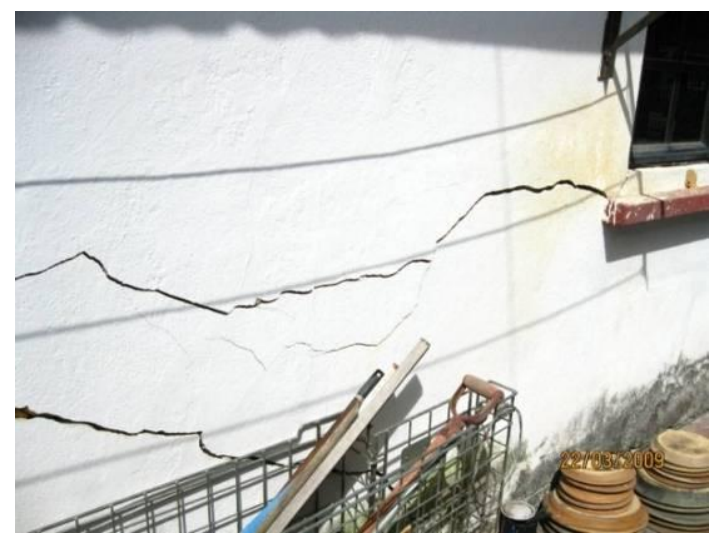

Retak sangat besar (37.9mm lebar) pada dinding di bilik utiliti Rumah 13

(Bahagian bangunan tambahan di tingkat bawah)

\section{Rajah 4: Kategori-kategori lebar retak bangunan kajian.}

Berdasarkan Jadual 1, Jadual 2 dan Rajah 4, didapati kategori lebar retak sangat besar berlaku sama ada pada elemen dinding atau lantai di bahagian bangunan tambahan Rumah 13, Rumah 14, Rumah 15, Rumah 16, Rumah 18 dan Rumah 19. 
Tinjauan awal yang dilakukan terhadap kawasan pembinaan baru berhampiran mendapati terdapat kerja-kerja pengorekan tanah di bahagian belakang deretan bangunan-bangunan tersebut. Oleh itu, retak sangat besar tersebut dijangka berpunca daripada pergerakan tanah akibat perubahan kandungan air impak kerja-kerja pengorekan dan impak gegaran daripada hentakan mesin cerucuk pembinaan baru berhampiran. Walau bagaimanapun, Rumah 17 tidak terdapat kategori lebar retak sangat besar pada elemen bangunannya dijangka disebabkan oleh reka bentuk dan kerja pembinaan bahagian bangunan tambahan yang berkualiti. Maklumat-maklumat dan dokumen-dokumen awal yang diperoleh menunjukkan dalam deretan tujuh buah bangunan tersebut, didapati hanya Rumah 17 sahaja yang mempunyai kelulusan pelan bangunan bagi sambungan dan ubah suaian rumah kediaman daripada MPSJ.

Berdasarkan Jadual 1, Jadual 2 dan Rajah 4 juga, didapati bahagian bangunan asal bagi kesemua 28 buah bangunan kajian berlaku retak sangat kecil dan retak kecil. Keretakan dijangka berpunca daripada pengembangan dan pengecutan bahan binaan akibat perubahan kandungan kelembapan dan perubahan suhu serta usia bangunan. Retak sederhana hingga retak sangat besar yang terdapat di bahagian bangunan asal pula hanya berlaku pada dinding tembok dan lantai kaki lima di anjung. Keretakan dijangka berpunca daripada reka bentuk dinding tembok dan lantai kaki lima yang sememangnya tiada asas serta mendapan tanah secara semula jadi akibat tekanan beban hidup dan beban mati contohnya berat kenderaan. Selebihnya, retak sederhana hingga retak sangat besar berlaku pada elemen-elemen bangunan di bahagian bangunan tambahan/ ubah suaian. Sementara itu, Jadual 3 menunjukkan ukuran numerik lebar retak bagi keseluruhan bangunan kajian ini. 
Jadual 3: Ukuran numerik lebar retak bagi keseluruhan bangunan kajian.

\begin{tabular}{|c|c|c|c|c|c|}
\hline \multirow[t]{2}{*}{ Ukuran } & \multicolumn{5}{|c|}{ Lebar Retak (mm) } \\
\hline & $\begin{array}{c}\text { Sangat } \\
\text { Kecil } \\
(<1.0)\end{array}$ & $\begin{array}{l}\text { Kecil } \\
(<5.0)\end{array}$ & $\begin{array}{c}\text { Sederhana } \\
(<\mathbf{1 5 . 0})\end{array}$ & $\begin{array}{c}\text { Besar } \\
(<25.0)\end{array}$ & $\begin{array}{c}\text { Sangat } \\
\text { Besar } \\
(\geq 25.0)\end{array}$ \\
\hline Minimum & 0.1 & 1.0 & 5.0 & 15.0 & 26.4 \\
\hline Maksimum & 0.9 & 4.7 & 14.3 & 24.1 & 60.0 \\
\hline Min & 0.5 & 2.2 & 8.6 & 19.4 & 35.4 \\
\hline Mod & 0.5 & 1.0 & 5.0 & 20.0 & 27.7 \\
\hline
\end{tabular}

Berdasarkan Jadual 3, ukuran minimum dan maksimum adalah masing-masing menunjukkan nilai cerapan paling rendah dan paling tinggi bagi setiap kategori lebar retak. Ini bermaksud, nilai lebar retak paling rendah yang direkodkan di tapak pemeriksaan ialah $0.1 \mathrm{~mm}$ manakala nilai lebar retak paling tinggi pula ialah $60.0 \mathrm{~mm}$. Ukuran min menunjukkan nilai purata lebar retak bagi setiap kategori lebar retak dalam kajian ini. Ukuran mod pula menunjukkan nilai lebar retak yang paling kerap wujud bagi setiap kategori lebar retak. Didapati nilai lebar retak yang paling kerap direkodkan di tapak pemeriksaan bagi kategori lebar retak sangat kecil ialah $0.5 \mathrm{~mm}$, retak kecil ialah $1.0 \mathrm{~mm}$, retak sederhana ialah $5.0 \mathrm{~mm}$, retak besar ialah $20.0 \mathrm{~mm}$ dan retak sangat besar ialah $27.7 \mathrm{~mm}$. Jadual 4 pula menunjukkan koefisien korelasi antara aras-aras bangunan bagi keseluruhan bangunan kajian ini. 
Jadual 4: Koefisien korelasi antara aras-aras bangunan kajian.

\begin{tabular}{|c|c|c|c|c|}
\hline & & & Tingkat bawah & $\begin{array}{r}\text { Tingkat } \\
\text { atas }\end{array}$ \\
\hline \multirow{6}{*}{$\begin{array}{l}\text { Spearman's } \\
\text { rho }\end{array}$} & \multirow{3}{*}{ Tingkat bawah } & Koefisien & 1.000 & .325 \\
\hline & & korelasi & . & .092 \\
\hline & & Nilai $p$ & & \\
\hline & \multirow[t]{3}{*}{ Tingkat atas } & Koefisien & .325 & 1.000 \\
\hline & & korelasi & .092 & \\
\hline & & Nilai $\mathrm{p}$ & & \\
\hline
\end{tabular}

Korelasi adalah signifikan pada aras keertian 0.05 .

Berdasarkan Jadual 4, tiada hubungan signifikan antara tingkat bawah dan tingkat atas bangunan. Ini bermaksud, keretakan yang berlaku di tingkat bawah tidak mempengaruhi keretakan yang berlaku di tingkat atas bangunan. Jadual 5 pula menunjukkan koefisien korelasi antara komponen-komponen bangunan bagi keseluruhan bangunan kajian ini. 
Jadual 5: Koefisien korelasi antara komponen-komponen bangunan kajian.

\begin{tabular}{|c|c|c|c|c|c|c|c|c|c|c|c|c|c|}
\hline & & & Anjung & $\begin{array}{r}\text { Ruang } \\
\text { tamu }\end{array}$ & Dapur & $\begin{array}{r}\text { Bilik } \\
\text { utiliti }\end{array}$ & Tandas 3 & $\begin{array}{r}\text { Ruang } \\
\text { keluarga }\end{array}$ & Bilik 1 & Bilik 2 & Bilik 3 & Tandas 1 & Tandas 2 \\
\hline \multirow{18}{*}{$\begin{array}{l}\text { Spearman's } \\
\text { rho }\end{array}$} & Anjung & Koefisien korelasi & 1.000 & .272 & .281 & .135 & .142 & .161 & -.088 & -.032 & .131 & -.028 & .205 \\
\hline & & Nilai p & . & .233 & .184 & .586 & .543 & .452 & .737 & .887 & .583 & .932 & .523 \\
\hline & Ruang & Koefisien korelasi & .272 & 1.000 & $.498 *$ & .435 & .348 & .139 & .318 & .347 & -.089 & .156 & -.151 \\
\hline & tamu & Nilai $\mathrm{p}$ & .233 & . & .030 & .071 & .244 & .477 & .289 & .134 & .762 & .667 & .699 \\
\hline & Dapur & Koefisien korelasi & .281 & $.498 *$ & 1.000 & .137 & $.729 * *$ & .277 & .024 & .090 & .251 & .026 & -.307 \\
\hline & & Nilai $\mathrm{p}$ & .184 & .030 & $\cdot$ & .582 & .002 & .225 & .932 & .713 & .315 & .943 & .332 \\
\hline & Bilik & Koefisien korelasi & .135 & .435 & .137 & 1.000 & $.865 * *$ & .152 & -.010 & -.013 & .152 & -.358 & .360 \\
\hline & utiliti & Nilai $p$ & .586 & .071 & .582 & . & .000 & .534 & .972 & .959 & .574 & .345 & .307 \\
\hline & Tandas 3 & Koefisien korelasi & .142 & .348 & $.729 * *$ & $.865^{* *}$ & 1.000 & .349 & -.049 & .088 & .436 & .363 & .360 \\
\hline & & Nilai $\mathrm{p}$ & .543 & .244 & .002 & .000 & . & .243 & .917 & .764 & .180 & .548 & .540 \\
\hline & Ruang & Koefisien korelasi & .161 & .139 & .277 & .152 & .349 & 1.000 & $.683 * *$ & $.480 *$ & .404 & .593 & .274 \\
\hline & keluarga & Nilai $p$ & .452 & .477 & .225 & .534 & .243 & . & .007 & .037 & .108 & .054 & .414 \\
\hline & Bilik 1 & Koefisien korelasi & -.088 & .318 & .024 & -.010 & -.049 & $.683 * *$ & 1.000 & -.082 & -.011 & $\cdot$ & .232 \\
\hline & & Nilai $p$ & .737 & .289 & .932 & .972 & .917 & .007 & . & .741 & .999 & . & .580 \\
\hline & Bilik 2 & Koefisien korelasi & -.032 & .347 & .090 & -.013 & .088 & $.480 *$ & -.082 & 1.000 & $.727 * *$ & .064 & .173 \\
\hline & & Nilai $p$ & .887 & .134 & .713 & .959 & .764 & .037 & .741 & . & .002 & .861 & .681 \\
\hline & Bilik 3 & Koefisien korelasi & .131 & -.089 & .251 & .152 & .436 & .404 & -.011 & $.727 * *$ & 1.000 & -.216 & \\
\hline & & Nilai p & .583 & .762 & .315 & .574 & .180 & .108 & .999 & .002 & . & .607 & \\
\hline
\end{tabular}




\begin{tabular}{|c|c|c|c|c|c|c|c|c|c|c|c|c|}
\hline Tandas 1 & Koefisien korelasi & -.028 & .156 & .026 & -.358 & .363 & .593 & & .064 & -.216 & 1.000 & \\
\hline & Nilai $\mathrm{p}$ & .932 & .667 & .943 & .345 & .548 & .054 & . & .861 & .607 & . & \\
\hline Tandas 2 & Koefisien korelasi & .205 & -.151 & -.307 & .360 & .360 & .274 & .232 & .173 & & . & 1.000 \\
\hline & Nilai $\mathrm{p}$ & .523 & .699 & .332 & .307 & .540 & .414 & .580 & .681 & & . & \\
\hline
\end{tabular}

**. Korelasi adalah signifikan pada aras keertian 0.01 .

*. Korelasi adalah signifikan pada aras keertian 0.05. 
Berdasarkan Jadual 5, didapati terdapat hubungan signifikan antara ruang tamu dengan dapur, dapur dengan tandas 3 dan bilik utiliti dengan tandas 3. Ini disebabkan oleh kedudukan komponenkomponen tersebut adalah bersebelahan antara satu sama lain di tingkat bawah bangunan. Tingkat bawah bangunan mengandungi komponen anjung, ruang tamu, dapur, bilik utiliti dan tandas 3. Rajah 5 menunjukkan contoh lakaran pelan lantai tingkat bawah salah sebuah bangunan kajian iaitu Rumah 11.

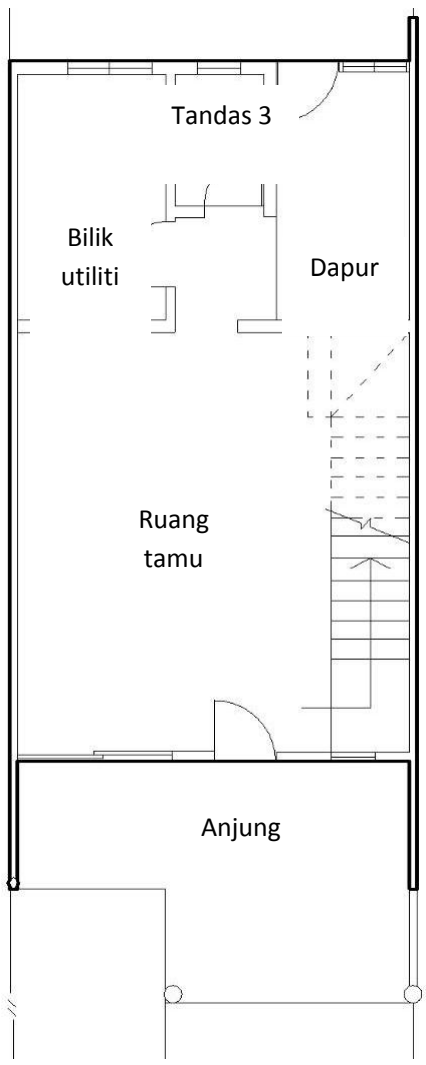

\section{Rajah 5: Lakaran pelan lantai tingkat bawah Rumah 11.}

Berdasarkan Rajah 5, komponen-komponen bangunan yang bersebelahan antara satu sama lain berkongsi beberapa elemen bangunan yang sama seperti dinding, rasuk dan tiang. Oleh itu, apabila berlaku keretakan sepanjang sambungan di antara dinding dengan rasuk di ruang tamu, keretakan juga berlaku sepanjang sambungan di antara dinding dengan rasuk di dapur kerana kedua-dua komponen tersebut berkongsi dinding dan rasuk menggalas beban yang sama. Walau bagaimanapun, keretakan yang berlaku bukanlah retak tembus dan dijangka berpunca daripada perbezaan koefisien pengembangan bahan-bahan binaan tersebut. Rajah 6 menunjukkan contoh lakaran keretakan sepanjang sambungan di antara dinding dengan rasuk di dapur rumah 16. Keretakan yang sama juga telah berlaku sepanjang sambungan di antara dinding dengan rasuk di ruang tamu. 


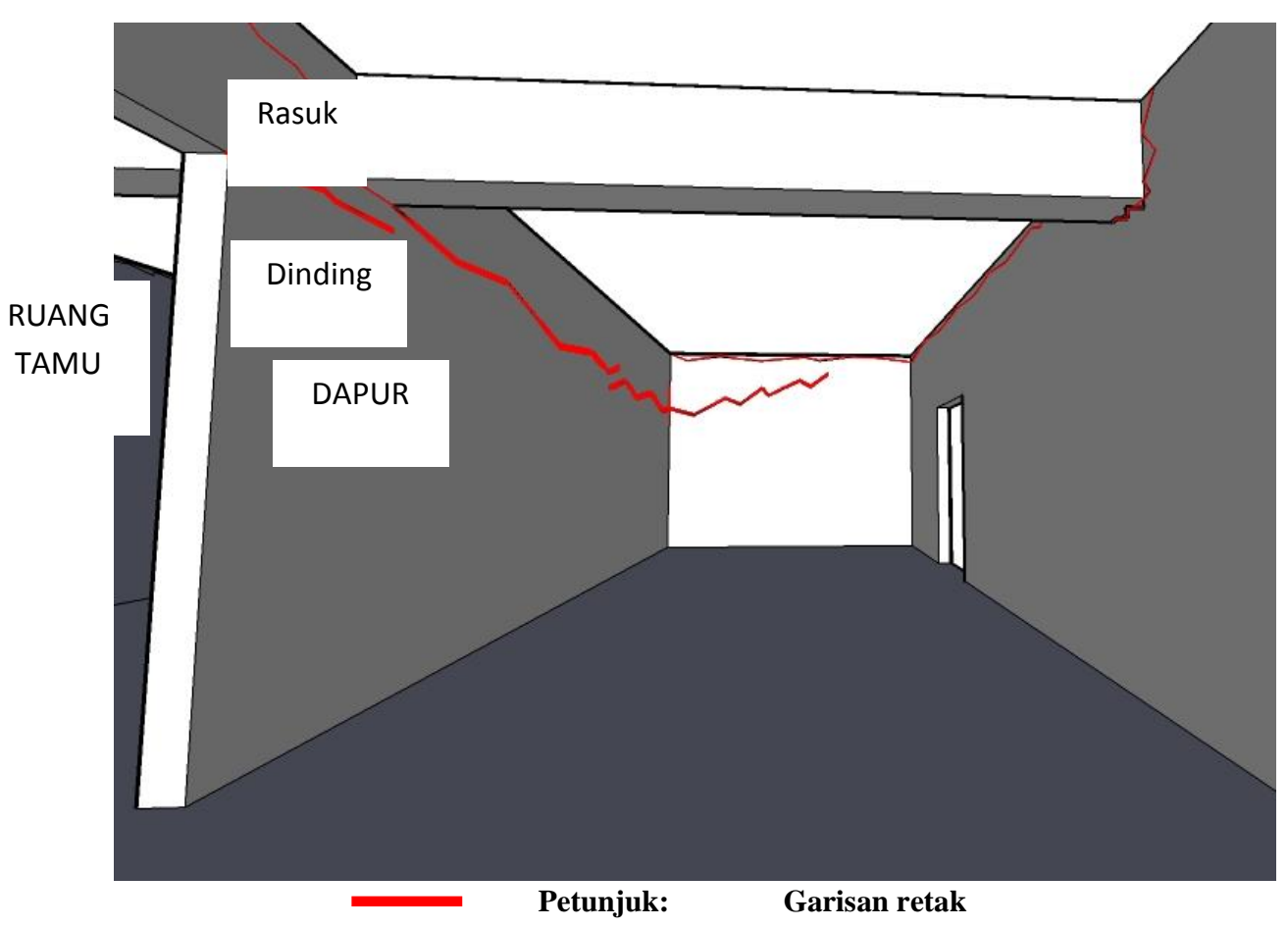

Rajah 6: Lakaran keretakan di dapur Rumah 16.

Di samping itu, didapati terdapat hubungan signifikan antara ruang keluarga dengan bilik 1, ruang keluarga dengan bilik 2 dan bilik 2 dengan bilik 3. Ini disebabkan oleh kedudukan komponenkomponen tersebut adalah bersebelahan antara satu sama lain di tingkat atas bangunan. Tingkat atas bangunan mengandungi komponen ruang keluarga, bilik 1, bilik 2, bilik 3, tandas 1 dan tandas 2. Rajah 7 menunjukkan contoh lakaran pelan lantai tingkat atas salah sebuah bangunan kajian iaitu Rumah 11. Berdasarkan Jadual 5 juga, didapati tiada hubungan signifikan antara mana-mana komponen tingkat bawah dengan komponen tingkat atas bangunan dan ini sejajar dengan koefisien korelasi seperti dalam Jadual 4 iaitu tiada hubungan signifikan antara aras-aras bangunan. Jadual 6 pula menunjukkan koefisien korelasi antara lokasi-lokasi bangunan bagi keseluruhan bangunan kajian ini. 


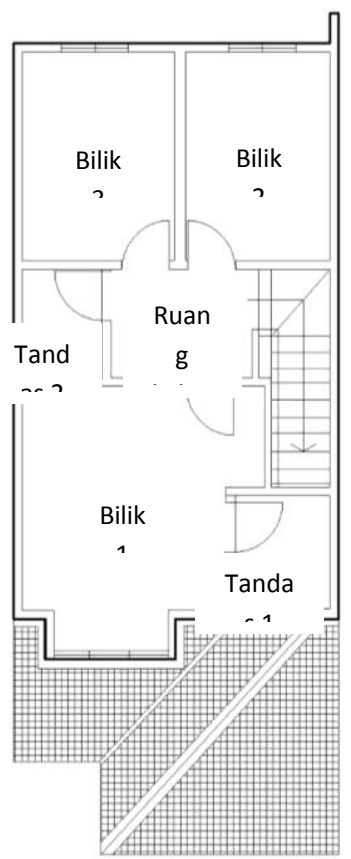

Rajah 7: Lakaran pelan lantai tingkat atas Rumah 11.

Jadual 6: Koefisien korelasi antara lokasi-lokasi bangunan kajian.

\begin{tabular}{|lllrr|}
\hline & & & Luaran & Dalaman \\
\hline \multirow{2}{*}{$\begin{array}{l}\text { Spearman's } \\
\text { rho }\end{array}$} & Luaran & Koefisien korelasi & 1.000 & .288 \\
& & Nilai p &. & .137 \\
& \multirow{2}{*}{ Dalaman } & Koefisien korelasi & .288 & 1.000 \\
& & Nilai p & .137 & \\
& & & \\
\hline
\end{tabular}

Korelasi adalah signifikan pada aras keertian 0.05 .

Berdasarkan Jadual 6, didapati tiada hubungan signifikan antara luaran dan dalaman bangunan. Ini bermaksud, keretakan yang berlaku di dalam tidak mempengaruhi keretakan yang berlaku di luar bangunan. Keretakan paling banyak berlaku di dalam bangunan iaitu sebanyak 364 retak berbanding di luar bangunan iaitu sebanyak 135 retak seperti dalam Jadual 2. Ini dijangka berpunca daripada agen perosak bangunan seperti air lebih banyak terdapat di dalam berbanding di luar bangunan. Penggunaan bangunan seperti manusia, paip bocor, air pembersihan serta kemasukan air ke dalam bangunan seperti air hujan yang masuk melalui bumbung, dinding atau secara tidak langsung melalui penyerapan telah menyumbang kepada kelembapan di dalam bangunan. Masalah kelembapan ini telah menyebabkan pengembangan dan pengecutan bahan-bahan binaan dan menghasilkan retak. Jadual 7 pula menunjukkan koefisien korelasi antara elemen-elemen bangunan bagi keseluruhan bangunan kajian ini. 
Jadual 7: Koefisien korelasi antara elemen-elemen bangunan kajian.

\begin{tabular}{|c|c|c|c|c|c|c|c|c|c|}
\hline & & & Dinding & $\begin{array}{l}\text { Dinding } \\
\text { tembok }\end{array}$ & Rasuk & Tiang & Lantai & $\begin{array}{r}\text { Lantai } \\
\text { kaki lima }\end{array}$ & Siling \\
\hline \multirow{14}{*}{$\begin{array}{l}\text { Spearman's } \\
\text { rho }\end{array}$} & Dinding & Koefisien korelasi & 1.000 & .009 & .465 & .363 & $.526^{*}$ & .150 & -.125 \\
\hline & & Nilai $\mathrm{p}$ & & .966 & .353 & .548 & .036 & .465 & .749 \\
\hline & Dinding & Koefisien korelasi & .009 & 1.000 & .224 & .949 & .017 & .341 & .082 \\
\hline & tembok & Nilai $p$ & .966 & . & .718 & .051 & .952 & .120 & .846 \\
\hline & Rasuk & Koefisien korelasi & .465 & .224 & 1.000 & $1.000 * *$ & .459 & -.101 & . \\
\hline & & Nilai $p$ & .353 & .718 & . & . & .437 & .848 & . \\
\hline & Tiang & Koefisien korelasi & .363 & .949 & $1.000 * *$ & 1.000 & $1.000 * *$ & -.154 & . \\
\hline & & Nilai $p$ & .548 & .051 & . & . & . & .805 & . \\
\hline & Lantai & Koefisien korelasi & $.526 *$ & .017 & .459 & $1.000 * *$ & 1.000 & .043 & -.309 \\
\hline & & Nilai $p$ & .036 & .952 & .437 & . & . & .878 & .500 \\
\hline & Lantai kaki & Koefisien korelasi & .150 & .341 & -.101 & -.154 & .043 & 1.000 & -.104 \\
\hline & lima & Nilai $p$ & .465 & .120 & .848 & .805 & .878 & . & .825 \\
\hline & Siling & Koefisien korelasi & -.125 & .082 & . & . & -.309 & -.104 & 1.000 \\
\hline & & Nilai $p$ & .749 & .846 & . & . & .500 & .825 & \\
\hline
\end{tabular}


Berdasarkan Jadual 7, didapati terdapat hubungan signifikan antara dinding dengan lantai, rasuk dengan tiang dan tiang dengan lantai. Ini disebabkan oleh elemenelemen bangunan ini adalah struktur utama menggalas beban yang bersambung antara satu sama lain. Sebagai contoh, keretakan berlaku sepanjang sambungan di antara dinding dengan lantai, sepanjang sambungan di antara rasuk dengan tiang dan sepanjang sambungan di antara tiang dengan lantai. Jadual 8 pula menunjukkan koefisien korelasi antara bahagian-bahagian bangunan bagi keseluruhan bangunan kajian ini.

Jadual 8: Koefisien korelasi antara bahagian-bahagian bangunan kajian.

\begin{tabular}{|lllrr|}
\hline & & & Asal & Tambahan/ \\
& & & ubah suaian \\
& & & & \\
Spearman's & Asal & Koefisien korelasi & 1.000 & .118 \\
rho & Nambahan/ ubah & Koefisien korelasi &. & .567 \\
& suaian & Nilai p & .118 & 1.000 \\
& & .567 &. \\
\end{tabular}

Korelasi adalah signifikan pada aras keertian 0.05 .

Berdasarkan Jadual 8, didapati tiada hubungan signifikan antara bahagian bangunan asal dengan bahagian bangunan tambahan/ ubah suaian. Keretakan yang berlaku pada bahagian bangunan tambahan tidak mempengaruhi bahagian bangunan asal. Ini disebabkan oleh kedua-dua bahagian bangunan tersebut disokong oleh asas atau struktur berasingan. Kebanyakan keretakan yang berlaku pada bahagian bangunan tambahan adalah dalam kategori lebar retak sederhana hingga retak sangat besar manakala pada bahagian bangunan asal adalah dalam kategori lebar retak sangat kecil dan retak kecil seperti dalam Jadual 2.

Sesungguhnya, tahap keretakan yang berlaku pada bahagian bangunan asal bagi kesemua 28 buah bangunan kajian adalah retak estetik yang hanya memberi kesan terhadap rupa bentuk bangunan. Walau bagaimanapun, dijangka tahap keretakan yang 
berlaku pada bahagian bangunan tambahan bagi 6 buah bangunan kajian adalah retak kestabilan yang memberi kesan terhadap integriti struktur bangunan tambahan tersebut.

\section{Kesimpulan dan cadangan}

Berdasarkan laporan-laporan dalam akhbar tempatan dan maklumat-maklumat daripada PBT, terdapat beberapa buah kes aduan tentang impak kerja pembinaan terhadap fizikal bangunan sekitar berlaku sejak beberapa tahun kebelakangan ini. Sehubungan itu, kajian ini dijalankan terhadap sebuah kes aduan yang diterima oleh salah sebuah PBT iaitu MPSJ daripada pemilik-pemilik bangunan di Taman Wawasan, Pusat Bandar Puchong tentang impak kerja pembinaan baru berhampiran terhadap fizikal bangunan mereka. Kajian ini dijalankan untuk mengenal pasti langkah komprehensif yang perlu dilakukan oleh MPSJ bagi menyelesaikan kes aduan yang diterima daripada pemilikpemilik bangunan sekitar terbabit.

Berdasarkan pemeriksaan visual bangunan yang dilakukan, didapati kesemua bangunan kajian mengalami keretakan pada beberapa lokasi, struktur dan elemen bangunan dengan beberapa tahap, bentuk dan lebar keretakan seperti yang didakwa oleh pemilik-pemilik bangunan terbabit. Walau bagaimanapun, punca primer keretakan bangunan yang berlaku adalah sukar ditentukan. Terdapat kenyataan daripada pemilik bangunan contohnya “... dahulu dinding rumah saya hanya mengalami keretakan sepanjang $1.0 \mathrm{~m}$ tetapi apabila kerja pembinaan baru berhampiran tersebut dijalankan, keretakan dinding rumah saya telah bertambah menjadi sepanjang 2.0 m”. Apabila dakwaan seperti ini timbul, banyak masa dibazirkan hanya untuk menentukan kesahihan kenyataan tersebut.

Oleh itu, dicadangkan MPSJ mewujudkan satu garis panduan di peringkat tempatan iaitu bagi setiap pembinaan baru yang akan dijalankan mestilah dihasilkan terlebih dahulu laporan keadaan bangunan-bangunan sedia ada di sekitarnya. Garis panduan ini perlu diwujudkan oleh MPSJ khasnya dan PBT amnya bagi menangani kes aduan sebegini yang mungkin akan berlaku lagi sejajar dengan jangkaan pertumbuhan kukuh industri pembinaan dalam tempoh akhir Rancangan Malaysia Kesembilan (20082010). 


\section{Rujukan}

Ahmad, R. (2004). Panduan kerja-kerja pemeriksaan kecacatan bangunan. Batu Caves: Building \& Urban Development Institute.

Berita Harian. (2008). Pemilik dakwa projek pangsapuri punca rumah retak. Dikutip Januari 13, 2009, daripada laman web: http://www.hba.org.my.

Building Research Establishment Limited. (1991). BRE Digest 361 Why do buildings crack?. United Kingdom: BRE Press.

Carillion Services Limited. (2001). Defects in buildings: symptoms, investigation, diagnosis and cure. United Kingdom: The Stationery Office.

Construction Industry Development Board. (2007). Executive summary Construction Industry Master Plan Malaysia 2006-2015. Dikutip Januari 21, 2009, daripada laman web: http://www.cream.com.my.

Eldridge, H.J. (1976). Common defects in buildings. London: Her Majesty's Stationery Office.

Foster, J.J. 2001. Data analysis using SPSS for Windows new edition versions 8 to 10: a beginner's guide. London: SAGE.

Harian Metro. (2008). Macam bom jangka. Dikutip Januari 13, 2009, daripada laman web: http://www.mbi.gov.my.

Jabatan Kerja Raya. (2007). Pengenalan struktur, reka bentuk \& komponen bangunan. Dikutip Mei 25, 2010, daripada laman web: http://www.jkr.terengganu.gov.my.

Johnson, R.W. (2002). The significance of crack in low-rise buildings. Structural Survey 20(5): 155-161. Dikutip Oktober 20, 2009, daripada laman web: http://www.emerald-library.com.

Nurul Azam Haron, Salihuddin Hassim, Mohd Razali Abd Kadir \& Mohd Saleh Jaafar. (2005). Building cost comparison between conventional and formwork system. Jurnal Teknologi 43(B): 1-11. Dikutip Mei 25, 2010, daripada laman web: http://www.penerbit.utm.my.

Panchdhari, A.C. (2003). Maintenance of buildings. New Delhi: New Age International (P) Limited.

Rahaya Md. Jamin. (2006). Impak pembangunan terhadap alam sekitar dan pengurusannya di Kemaman. Tesis Sarjana (Tidak diterbitkan), Pusat Pengajian Siswazah, Universiti Kebangsaan Malaysia. 
Ruzana Mohamed. (1999). Impak pembangunan KLIA terhadap alam sekitar: dampak sosioekonomi. Tesis Sarjana (Tidak diterbitkan), Pusat Pengajian Siswazah, Universiti Kebangsaan Malaysia.

Zuzyanna Kasman. (2007). Impak pembangunan terhadap alam sekitar dan pengurusannya di Seremban. Tesis Sarjana (Tidak diterbitkan), Pusat Pengajian Siswazah, Universiti Kebangsaan Malaysia. 